\title{
Huisache Control by Power Grubbing
}

\author{
O.E. BONTRAGER, C.J. SCIFRES, AND D.L. DRAWE
}

\begin{abstract}
Low-energy mechanical grubbing of huisache densities of 181 to 689 trees/ha, 1.8 to $2.6 \mathrm{~m}$ tall, reduced the canopy by 90 to $96 \%$ and killed 65 to $81 \%$ of the treated plants on the Coastal Prairie. Grubbing time was a linear function of huisache density and varied from $0.5 \mathrm{hr} / \mathrm{ha}$ for removal of 181 plants to $1.6 \mathrm{hr} / \mathrm{ha}$ for removal of 689 plants. Resprouting rapidly occurred from residual stem tissues if huisache stems were not grubbed to the first lateral root. Grubbing depth had to be increased as basal trunk diameter increased to ensure huisache mortality. Plants 1 to $4 \mathrm{~cm}$ in diameter were killed by grubbing 5 to $10 \mathrm{~cm}$ deep; plants with diameters of 6 to $15 \mathrm{~cm}$ required grubbing as deep as $20 \mathrm{~cm}$ for elimination. Soil disturbed by grubbing revegetated naturally within 15 months after treatment. Standing grass crop was unaffected 20 months after grubbing; but the relative proportions of cool-season grasses, Texas wintergrass and Canada wildrye, were increased, especially in the pits.
\end{abstract}

Huisache (Acacia farnesiana) is a vigorous invader of south Texas rangeland. It now occurs on about 1 million ha of productive grazing lands, and its rate of spread throughout tropical and semitropical areas of the Americas is of major concern to ranchers (Smith and Rechenthin 1964). Huisache is one of the most important species in the mixed-brush (ProsopisAcacia) complex of south Texas and may form almost pure stands, especially following mechanical brush control. Dense huisache stands greatly reduce efficiency of range livestock production and seriously hamper management (Bovey and Meyer 1974).

Huisache is cited as the most formidable woody species of the Texas Coastal Prairie (Mutz et al. 1978). Its seeds, like those of honey mesquite (Prosopis glandulosa var. glandulosa), have high germination potential immediately upon dissemination,

Authors are research fellow, Rob and Bessie Welder Wildlife Foundation, Sinton, Texas. 78387; professor. The Texas Agricultural Experiment Station (Department of Range Science). Texas A\&M University, College Station, 77843; and assistant director. Rob and Bessie Welder Wildlife Foundation

This report was approved by the director, Texas Agr. Exp. Sta.. as TA-14039 and as Rob and Bessie Welder Wildlife Foundation Publication No. 214

The efforts of Julia Scifres in manuscript typing and preparation are greatly appreciated

Manuscript received February 22, 1978. especially if scarified and exposed to temperatures of 26 to $30^{\circ} \mathrm{C}$ (Scifres 1974). Once established, the seedlings grow rapidly and resprout readily following damage or top removal. Huisache sprouts may grow to almost half their original total plant height within 5 months after shredding (Powell et al. 1972). Thus, mechanical top removal results in only short-term suppression of huisache (Mutz et al. 1978) and gives the species competitive advantage over associated, slower growing woody plants. Almost pure, dense stands of huisache may develop within two to three growing seasons following brush control methods that disturb the soil.

Herbicides such as 2,4,5-T [(2,4,5-trichlorophenoxy) acetic acid] applied broadcast at rates of $2.2 \mathrm{~kg} / \mathrm{ha}$ or less only partially control huisache (Bovey et al. 1970). However, applications of $1.12 \mathrm{~kg} / \mathrm{ha}$ of picloram (4-amino-3,5,6-trichloropicolinic acid) combined with the same rate of 2,4,5-T in the fall or late spring control huisache. Huisache control by aerial spraying is often impractical because of adjacent susceptible crops. Individualplant treatments with oil or with herbicides in oil-based carriers effectively control huisache but economic constraints, especially oil and labor costs, seriously limit this approach except on low-density infestations.

Power grubbing has been used for brush control since the late 1930's (Dickson et al. 1940). Most power grubbing has been accomplished with $74.6 \mathrm{kw}$ (100 hp) or larger crawler tractors. However, a relatively small crawler tractor, $48.5 \mathrm{kw}$, was recently developed with an improved hydraulic system and "shift-on-the-go" transmission for more efficient grubbing of brush (Wiedemann et al. 1977). This "low-energy" grubber removed similar numbers of small to medium-sized honey mesquite trees more rapidly at lower cost than a $89.5-\mathrm{kw}$ unit. The low-energy grubber was most efficient for grubbing areas supporting no more than 120 to 160 trees/ha.

Objectives of this study were to (1) evaluate low-energy power grubbing for huisache management, (2) define the grubbing depth for controlling huisache, and (3) evaluate 
herbaceous vegetation response to huisache removal by grubbing on the Coastal Prairie.

\section{Materials and Methods}

\section{Study Site Description}

The research was conducted on the Rob and Bessie Welder Wildlife Refuge, $11.3 \mathrm{~km}$ north of Sinton, in the Coastal Bend region of the Gulf Prairies and Marshes vegetational area of Texas. Soils of the study area are Cumulic Haplustolls of the Sinton and Odem series. The Sinton complex has a characteristically thick, gray, loam A horizon and a calcareous $\mathrm{C}$ horizon. The lighter-textured Odem soil has a fine sandy to sandy loam A horizon and a deep fine sandy $\mathrm{C}$ horizon. Both soils are well drained and of moderate permeability.

Vegetation on both soils was dominated by light to moderately dense huisache stands composed of seedlings only a few centimeters tall to trees exceeding $5 \mathrm{~m}$ tall. Associated brush species included willow baccharis (Baccharis salicina), honey mesquite, blackbrush acacia (Acacia rigidula), spiny hackberry (Celtis pallida), chittimwood (Bumelia languinosa), and Texas colubrina (Colubrina texensis). Herbaceous species on the Sinton sandy clay loam site included various Paspalums, knotroot bristlegrass (Setaria geniculata), vine mesquite (Panicum obtusum), Texas wintergrass (Stipa leucotricha), and forbs (Ruellia, Phyla, Croton, and Aster spp.). Herbaceous species on the Odem soils included little bluestem (Schizachyrium scoparium), Pan American balsamscale (Elyonurus tripsacoides), knotroot bristlegrass, Texas wintergrass, Texas virgin's bower (Clematis drummondii), American snoutbean (Rhynocosia americana), and Croton spp.

\section{Experimental Procedures}

The low-energy grubber described by Wiedemann et al. (1977) 1 was used to grub huisache from 14, 1- to 2-ha plots on August 26, 1975. Prior to treatment, huisache density, canopy cover, and average height were estimated by the point-center-quarter method (Cottam and Curtis 1956) from 20 points equally spaced on a diagonal line across each plot. During treatment, grubbing time (hr) for each plot and number of trees grubbed per plot were recorded. The relationship between the dependent variable (grubbing time) and the independent variable (huisache density) was evaluated utilizing regression analysis. Simple linear, logarithmic, and log-log functional relationships were inspected. The best-fit functional relationship was based on significance of the $b$-value at the $95 \%$ level of probability based on the $t$-criterion, the highest correlation coefficient $(r)$ and the lowest coefficient of variation. Difference in grubbing time that might be attributed to soil types was tested by conducting individual regression analyses based on the best-fit functional relationships and comparing slope differences with a $t$-test at the $95 \%$ level of probability. Since regression coefficients were not different, results from different soils were pooled for further interpretation.

Immediately following grubbing, 80 grubbed trees were selected along a $10-\mathrm{m}$ wide diagonal belt transect in each plot, permanently marked, and depth of grubbing and taproot diameter were measured. The number of grubbed plants which developed regrowth, regrowth height, and new seedlings were recorded in April 1977. Data were augmented by recording the original depth of resprout origin on 65 additional, randomly selected plants.

Selection of plots was stratified for evaluation of herbaceous vegetation based on pretreatment vegetation characteristics as related to soil type. Three untreated plots, randomly located among the grubbed plots, were selected at the same time. Forb density was recorded in $30,0.25 \mathrm{~m}^{2}$ quadrats located at 3.05-m intervals along a permanent line in each plot in August 1976 and May 1977. Basal contacts of herbaceous vegetation were recorded in August 1975, prior to treatment, and in May 1977 using 50 inclined, 10-point frames at $3.05-\mathrm{m}$ intervals along the permanent lines.

Fifteen months following grubbing (November 11, 1976), foliar cover of herbaceous vegetation was estimated in 25 , randomly located

The grubbing treatments were installed on a contract basis by H.T. Wiedemann. pits in each grubbed plot. Foliar contacts were recorded from fou 10-point frame samples radially positioned from the center of each $p$ in the cardinal directions. Five wire-mesh grazing exclosures, 4.5 t in circumference and $2 \mathrm{~m}$ tall, with 10 by $10-\mathrm{cm}$ openings wer established on each plot. Standing crop was harvested to a 2.5 -cI stubble height in $0.25-\mathrm{m}^{2}$ quadrats from the center of each exclosure $\mathrm{i}$ April, June, September, and November 1976 and in May 1977 Herbage samples were dried at $60^{\circ} \mathrm{C}$ for 1 week and weighec

Grubbing treatments were randomly allocated to seven plots on eac soil. Three plots were not treated. Analyses of variance of all attribute were based on a two-way classification with treatments (grubbing an no treatment) nested within soils. All attributes were handled in th same manner with analyses based on unequal replication but prc portional subclass numbers (Steel and Torrie 1960). Where appli cable, mean separation was accomplished with Duncan's new multipl range test.

A second experiment was installed near Bryan, Texas, in the Pos Oak (Quercus stellata) Savannah to augment data collected nea Sinton on the relationship of grubbing depth and sprout origin. I August 1976, 50 small $(<0.7 \mathrm{~m}$ tall $)$ huisache plants growing on Gowen clay loam (Cumulic Hapludoll) were hand grubbed. Ten plant were either sheared off at ground line or at $2.5,5,10$ or $15 \mathrm{~cm}$ belor ground line. Percentage of huisache killed and depth of the lowes sprout of surviving plants were determined in May 1977.

\section{Results and Discussion}

Before treatment (August 1975), huisache canopy cover wa $19.4 \%$ on the Sinton clay loam and $15.1 \%$ on the Odem sand loam. Pretreatment density of huisache ranged from 181 to 80 . plants/ha. Twenty months following treatment, huisach canopy cover on the Sinton sandy clay loam was reduced $b$ : $92 \%$ based on pretreatment measurements, and $97 \%$ of th topgrowth was removed on the Odem sandy loam (Table 1). A the time of grubbing, huisache averaged from 1.8 to $2.6 \mathrm{~m}$ tal with a trend toward taller plants on the Odem sandy loam Fifteen and 99 plants/ha were missed by the grubbing operation on the Odem and Sinton soils, respectively. Huisache plant missed by the grubber were less than $30 \mathrm{~cm}$ tall at the time o treatment and apparently were obscured by the dense gras: cover. The growth rate of huisache described by Powell et al (1972) was evidenced at 20 months after treatment by height $o$ regrowth and of huisache missed during the grubbing operation Regrowth was 0.8 to $0.9 \mathrm{~m}$ tall after 20 months and huisach plants missed by the grubber had grown to 1.2 to $1.4 \mathrm{~m}$ tall Thus, based on an average original height across treatments $o$ $2.2 \mathrm{~m}$, huisache regrowth was nearly $40 \%$ of the original heigh after 20 months. Although grubbing removed over $90 \%$ of thi huisache canopy and killed about $80 \%$ of the population, thr need for followup improvement methods was apparent within ? years after treatment.

At time of treatment, considerable variation in grubbin: depth was noticed. This variation was partly attributable $t_{t}$ operator reaction to tree size since larger plants were generall: approached more slowly in an attempt to grub them deeper However, the variation was caused, in large part, by differentia ground cover of herbaceous vegetation. Heavy cover of surfac vegetation allowed the blade to skip on the surface rather tha: immediately cut into the soil, resulting in shallow grubbing Based on evaluations 20 months after grubbing, there was trend toward increased percentage of huisache killed a grubbing depth increased from an average of 9 to $20 \mathrm{~cm}$ (Tabl 2). Huisache survival apparently depended on extension of sten tissues below ground line since no resprouts originated fron 
Table 1. Average huisache density (plants/ha) and average plant height $(\mathrm{m})$ at the time of grubbing in August 1975 , and plants remaining and their height and average canopy reduction (\%) after 20 months on two soils on the Welder Wildlife Refuge near Sinton, Texas. ${ }^{1}$

\begin{tabular}{|c|c|c|c|c|c|c|c|c|}
\hline \multirow[b]{4}{*}{ Treatment } & & & \multicolumn{5}{|c|}{ Post treatment stand } & \multirow{4}{*}{$\begin{array}{l}\text { Canopy } \\
\text { reduction }\end{array}$} \\
\hline & & & & Density & & & & \\
\hline & \multicolumn{2}{|c|}{ Original stand } & \multirow{2}{*}{$\begin{array}{l}\text { Missed } \\
\text { plants }\end{array}$} & \multirow{2}{*}{$\begin{array}{c}\text { Plants } \\
\text { resprouting }\end{array}$} & \multirow{2}{*}{$\begin{array}{l}\text { Invading } \\
\text { seedlings }{ }^{2}\end{array}$} & \multirow{2}{*}{$\begin{array}{c}\text { Huisache } \\
\text { missed }\end{array}$} & \multirow[b]{2}{*}{ Resprouts } & \\
\hline & Density & $\mathrm{Ht}$ & & & & & & \\
\hline & \multicolumn{8}{|c|}{ Sinton sandy clay loam } \\
\hline None & $759 \mathrm{c}$ & $2.0 \mathrm{a}$ & - & - & $42 \mathrm{a}$ & - & - & 0 a \\
\hline \multirow[t]{2}{*}{ Grubbed } & $588 \mathrm{~b}$ & $1.8 \mathrm{a}$ & $99 \mathrm{~b}$ & $123 \mathrm{~b}$ & 49 a & $1.4 \mathrm{a}$ & $0.8 \mathrm{a}$ & $92 \mathrm{~b}$ \\
\hline & \multicolumn{8}{|c|}{ Odem sandy loam } \\
\hline None & $582 \mathrm{~b}$ & $2.3 \mathrm{~b}$ & - & - & $46 \mathrm{a}$ & - & - & $0 \mathrm{a}$ \\
\hline Grubbed & 272 a & $2.6 \mathrm{~b}$ & $15 \mathrm{a}$ & $41 \mathrm{a}$ & $30 a$ & $1.2 \mathrm{a}$ & $0.9 \mathrm{a}$ & $97 \mathrm{~b}$ \\
\hline
\end{tabular}

'Means within a column followed by the same Ietter are not significantly different at the $95 \%$ level according to Duncan's new multiple range test.

? Invading huisache were about $30 \mathrm{~cm}$ tall at the post-treatment evaluation.

Table 2. Average grubbing depth $(\mathrm{cm})$, number of huisache removed (plants/ha) at the depth and percentage of population killed after 20 months on the Welder Wildlife Refuge near Sinton, Tex.

\begin{tabular}{lccc}
\hline Soil & $\begin{array}{c}\text { Avg. grubbing } \\
\text { depth' }\end{array}$ & $\begin{array}{c}\text { Huisache } \\
\text { removed }\end{array}$ & $\begin{array}{c}\text { Percentage } \\
\text { huisache killed' }\end{array}$ \\
\hline Sinton & $9 \mathrm{a}$ & 393 & $65 \mathrm{a}$ \\
Sinton & $13 \mathrm{~b}$ & 497 & $74 \mathrm{a}$ \\
Odem & $13 \mathrm{~b}$ & 261 & $70 \mathrm{a}$ \\
Odem & $14 \mathrm{~b}$ & 507 & $81 \mathrm{a}$ \\
Odem & $20 \mathrm{c}$ & 203 & $79 \mathrm{a}$
\end{tabular}

'Means followed by the same letter are not significantly different at the $95 \%$ level according to Duncan's new multiple range test.

root tissues. Of the plants inspected, those which had stems removed immediately below the junction of the first lateral root were killed. These observations indicate that vegetative regrowth following top removal of huisache follows a pattern similar to that described for honey mesquite (Scifres 1973).

Powell et al. (1972) noted that regrowth rapidly developed from stem segments left intact after top removal of huisache, and that sprout development followed a typical apical dominance pattern. In general, larger taproot diameters coincided with greater downward extensions of stem tissues capable of resprouting (Table 3 ). Huisache stem segments may be $20 \mathrm{~cm}$ or deeper on trees with taproots greater than 10 to $15 \mathrm{~cm}$ in diameter at the stem-root junction. Regardless of grubbing depth, the sprouts originated from stem tissues at 0.5 to $1.5 \mathrm{~cm}$ below the point of cut. At the grubbing depths of $9 \mathrm{~cm}$ or deeper, most of the plants were grubbed at the more shallow depths of the ranges. Therefore, average depth of resprout origin (Table

Table 3. Average grubbing depth $(\mathrm{cm})$, percentage of the resprouting huisache plants grubbed at that depth, the corresponding mean taproot diameter $(\mathrm{cm})$, and the depth of lowermost resprout $(\mathrm{cm})$ after 20 months on the Welder Wildlife Refuge near Sinton, Tex.

\begin{tabular}{lccc}
\hline \hline $\begin{array}{l}\text { Grubbing } \\
\text { depth' }\end{array}$ & $\begin{array}{c}\text { Percentage } \\
\text { of plants } \\
\text { treated }\end{array}$ & $\begin{array}{c}\text { Avg. } \\
\text { taproot } \\
\text { diam }\end{array}$ & $\begin{array}{c}\text { Depth } \\
\text { of lowest } \\
\text { resprout }\end{array}$ \\
\hline $0-2$ & 32 & 4.1 & 3.0 \\
$3-5$ & 15 & 6.1 & 6.6 \\
$6-8$ & 31 & 7.3 & 8.4 \\
$9-11$ & 15 & 7.9 & 10.7 \\
$12-14$ & 7 & 5.8 & 12.8 \\
\hline
\end{tabular}

' Grubbing depth of $0 \mathrm{~cm}$ indicates point of cut at soil surface.
3) does not exceed the lowermost depth of grubbing indicated by the tabled range.

The relationship between grubbing depth and resprout potential was also apparent with small huisache (taproot diameters of 1 to $4 \mathrm{~cm}$ ) that were hand grubbed near Bryan (Table 4). Removal of the stems at ground line killed none of the plants since the underground stem tissue was left intact. Most of the population $(60 \%)$ survived grubbing to $2.5 \mathrm{~cm}$ deep but grubbing to $5 \mathrm{~cm}$ deep killed $90 \%$ of the plants. As in the study near Sinton, sprouts usually developed 0.5 to $1.5 \mathrm{~cm}$ below the point of cut and always from stem tissue. Since the first lateral root usually occurred from 5 to $8 \mathrm{~cm}$ below the soil surface, grubbing to a depth of 10 or $15 \mathrm{~cm}$ completely controlled the population.

Table 4. Grubbing depth $(\mathrm{cm})$, depth of lowest sprout $(\mathrm{cm})$, and percentage of small huisache plants killed by hand grubbing after 9 months on a Gowen clay loam near Bryan, Tex.

\begin{tabular}{ccc}
\hline $\begin{array}{c}\text { Grubbing } \\
\text { depth }\end{array}$ & $\begin{array}{c}\text { Depth of lowest } \\
\text { sprout }\end{array}$ & $\begin{array}{c}\text { Plants } \\
\text { killed }^{1}\end{array}$ \\
\hline 0 (surface) & 2.8 & $0 \mathrm{a}$ \\
2.5 & 3.7 & $40 \mathrm{~b}$ \\
5 & 5.5 & $90 \mathrm{c}$ \\
10 & - & $100 \mathrm{c}$ \\
15 & - & $100 \mathrm{c}$ \\
\hline Mcans followed by the same letter are not significantly different at the $95 \%$ level \\
according to Duncan's new multiple range test.
\end{tabular}
according to Duncan's new multiple range test.

With the density range of 181 to 689 huisache plants/ha, grubbing time (hr/ha) was highly correlated $(r-0.88$; significant at $P<0.05$ ) with density (plants/ha) (Table 5). The

Table 5. Relationship of actual and predicted grubbing times (hr/ha) for selected huisache populations of varying densities (plants/ha) on two soils on the Welder Wildlife Refuge near Sinton, Tex.

\begin{tabular}{lccc}
\hline & & \multicolumn{2}{c}{ Grubbing time } \\
\cline { 3 - 4 } Soil & Plants grubbed & Actual & Predicted \\
\hline Odem & 181 & 0.50 & 0.49 \\
Odem & 203 & 0.50 & 0.54 \\
Odem & 261 & 0.80 & 0.68 \\
Sinton & 393 & 1.21 & 1.00 \\
Sinton & 497 & 1.11 & 1.25 \\
Odem & 507 & 1.20 & 1.27 \\
Sinton & 689 & 1.56 & 1.71
\end{tabular}

' Based on the relationship, grubbing time $=0.0567+0.0024$ (huisache density). 
relationship was best described by the lincar function, $Y-$ $0.0567+0.0024(X)$ where $Y=$ grubbing time and $X=$ huisache density. An exponential curve provided the best-fit in studies by Wiedemann et al. (1977) with honey mesquite for a density range of less than 20 to about 250 trees/ha. Since the lower densities of huisache grubbed in this study corresponded to the higher densities of honey mesquitc grubbed by Wiedemann et al. (1977), it is understandable that linearity would be suggested for the relationship in this study. Although grubbing efficiency did not vary with soils in this study, further research is needed to define the influence of heavier-textured soils on grubbing efficiency since huisache is also common on blackland range sites (Victoria and Lake Charles clays).

Grubbing relatively high densities of huisache resulted in substantial increases in bare ground immediately after treatment with surface disturbance roughly proportional to the number of huisache plants removed. Average size of disturbed areas (pits) was approximately $36 \mathrm{dm}^{2}$. Of particular interest was the potential influence of disturbance on botanical composition of herbaceous vegetation. Considering total land area, there was no change in the relative proportion of grasses $(69 \%)$ to forbs (29\%) from pretreatment evaluations in 1975 to evaluations in May 1977 on the Sinton sandy clay loam. However, there was an increase in the relative proportion of cool-season grasses to warm-season grasses such as hairyseed paspalum (Paspalum pubiflorum) and knotroot bristlegrass. Canada wildrye (Elymus canadensis) increased from 0 to $4 \%$ and Texas wintergrass increased from 3 to $21 \%$ of the botanical composition. On the Odem sandy loam, the proportion of grasses in the botanical composition increased slightly from pretreatment $(61 \%)$ to May $1977(68 \%)$. As on the Sinton soil, Canada wildrye increased from 0 to $2 \%$ and Texas wintergrass increased from 3 to $19 \%$ on grubbed plots over the study period. However, a notable increase, from 18 to $24 \%$, also occurred in the contribution of little bluestem to the botanical composition compared to pretreatment evaluations. These changes did not occur on untreated plots.

Forbs increased initially by invading the open pits on both sites. However, at 12 and 20 months after treatment, forb densities were not significantly different $(P>0.05)$ between untreated and grubbed plots on either soil, averaging 47 plants $/ \mathrm{m}^{2}$ compared to 34 forbs $/ \mathrm{m}^{2}$ on adjacent undisturbed plots. The difference in forb densities between treatments had decreased after 20 months with 36 plants $/ \mathrm{m}^{2}$ on untreated plots and 45 plants $/ \mathrm{m}^{2}$ on grubbed plots.

Most pits resulting from grubbing were essentially bare for 7 months after treatment, supporting only a few annual forbs and grasses. However, by mid-June 1976 (the summer after treatment), the pits were vegetated with Texas wintergrass, various Paspalums, knotroot bristlegrass and various forbs. By 15 months after treatment, foliar cover in the pits was no different than on adjacent undisturbed areas. At that time, grasses accounted for 62.5 and $43.8 \%$ of foliar cover in the pits on the Sinton sandy clay loam and Odem sandy loam, respectively.
Knotroot bristlegrass and vine mesquite were primary grasses occurring in pits on the sandy clay loam. On Odem soils, Texas wintergrass and knotroot bristlegrass were the primary grasses based on foliar cover.

Forbs accounted for $21.4 \%$ of the foliar cover on pits on the sandy clay loam but contributed only $6.7 \%$ to cover on the sandy loam after 15 months. Sawtooth fogfruit (Phyla incisa) was the most common forb on the sandy clay loam. Low growing vines, southern dewberry (Rubus trivalis) and Texas virgin's bower, provided $15 \%$ of the foliar cover on the pits on sandy loam sites with spiny aster (Aster spinosus) and Croton spp. the most common forbs.

Disturbance by grubbing tended to decrease overall grass standing crop during April 1976 where 400 or more trees/ha were removed the previous August. However, by June 1976 there was no difference in standing crop of grasses, regardless of site or grubbing treatment. Average standing crop of grasses was slightly higher on grubbed plots in September and November 1976 but there was no statistical difference among treatments in May 1977.

These data indicate that power grubbing will effectively control fairly dense stands of huisache, 1.8 to $2.6 \mathrm{~m}$ tall, on sandy loam and sandy clay loam sites with little or no lasting detrimental effect on herbaceous vegetation. At a 1977 contract cost of $\$ 21.00 / \mathrm{hr}$, estimated costs for various stand densities were $\$ 11.27$ for 200 plants/ha, $\$ 21.35$ for 400 plants/ha and $\$ 33.81$ for 600 plants/ha based on the prediction equation. These costs allow grubbing to compete with aerial broadcast applications of effective herbicides at 1977 contract prices. However, with any huisache management technique, followup treatments will be necessary to control resprouts and invading seedlings.

\section{Literature Cited}

Bovey, R.W., and R.E. Meyer. 1974. Mortality of honey mesquite and huisache seedlings from herbicides and top removal. Weed Sci. 22:276-279.

Bovey, R.W., J.R. Baur, and H.L. Morton. 1970. Control of huisache and associated species in south Texas. J. Range Manage. 23:47-50.

Cottam, G., and J.T. Curtis. 1956. The use of distance measures in phytosociological sampling. Ecology 37:451-460.

Dickson, R.E., B.G. Langley, and C.E. Fisher. 1940. Water and soil conservation experiments at Spur, Texas. Texas Agr. Exp. Sta. Bull. 587. 35 p.

Powell, J., T.W. Box, and C.V. Baker. 1972. Growth rate of sprouts after removal of huisache (Acacia farnesiana [L.] Willd.) (Leguminosae) in south Texas. Southw. Natur. 17:191-195.

Mutz, J.L., C.J. Scifres, D.L. Drawe, T.W. Box, and R.E. Whitson. 1978. Changes in range vegetation 14 years after mechanical brush treatment on the coastal prairie. Texas Agr. Exp. Sta. Bull. 1197. 16 p.

Scifres, C.J. (ed). 1973. Mesquite. Growth and development, management, economics, control, uses. Texas Agr. Exp. Sta. Res. Mon. 1. 84 p.

Scifres, C.J. 1974. Salient aspects of huisache seed germination. Southw. Natur. 18:383-392.

Smith, H.N., and C.A. Rechenthin. 1964. Grassland restoration. The Texas brush problem. U.S. Dep. Agr., Soil Conserv. Serv., Temple, Texas. 17 p.

Steel, R.G.D., and J.H. Torrie. 1960. Principles and Procedures of Statistics. McGraw-Hill Book Co., Inc. N.Y. 431 p.

Wiedemann, H.T., B.'T. Cross, and C.E. Fisher. 1977. Low-energy grubber for controlling brush. Trans. Amer. Soc. Agr. Engr. 20:210-213.

\section{Moving?}

Please let us know your new address. Send address changes to:

Society for Range management

2760 West Fifth Avenue

Denver, Colo. 80204 